\title{
Bone Marrow Stem Cell at the Earliest Stage of Myeloid Differentiation
}

National Cancer Institute

\section{Source}

National Cancer Institute. Bone Marrow Stem Cell at the Earliest Stage of Myeloid

Differentiation. NCI Thesaurus. Code C41061.

An undifferentiated cell which can undergo division and can give rise to any of the early stage myeloid cells. 